The Review of Education, Pedagogy, and Cultural Studies, 25:75-93 2003

Copyright (c) Taylor \& Francis Inc.

ISSN: 1071-4413 print

DOI: $10.1080 / 10714410390198949$

\title{
Contemporary Youth and the Postmodern Adventure
}

\section{Steven Best and Douglas Kellner}

Contemporary youth are major players in the postmodern adventure because it is they who will enter the future and further shape the world to come. ${ }^{1}$ The offspring of the baby boomers born in the 1940s, their identities are indelibly marked as "post"-postboomer, post-60s, posthistorical, postmodern. Yet they live in a present marred by extreme uncertainty, facing a future that is murky and unpredictable. For youth today, change is the name of the game and they are forced to adapt to a rapidly mutating and crisis-ridden world characterized by novel information, computer, and genetic technologies; a complex and fragile global economy; and a frightening era of war and terrorism. According to dominant discourses in the media, politics, and academic research, the everyday life of growing segments of youth is increasingly unstable, violent, and dangerous. The situation of youth is today marked by the dissolution of the family; growing child abuse and domestic conflict; drug and alcohol abuse; sexually transmitted diseases; poor education and crumbling schools; and escalating criminalization, imprisonment, and even state execution. These alarming assaults on youth are combined with massive federal cutbacks of programs that might give youth a chance to succeed in an increasingly difficult world.

Hence, today's youth are at risk in a growing number of ways and survival is a challenge. Ready or not, they will inherit a social world that is increasingly deteriorating and a natural world that is ever more savaged by industrial forces. Yet they also have access to exciting realms of cyberspace and the possibilities of technologies, identities, and entrepreneurial adventures unimagined by previous generations. Contemporary youth includes the best educated generation in history, the most technically sophisticated, and the most diverse and multicultural, making generalizations about youth in the present day precarious. 
In this study, we develop some concepts to outline a critical theory of youth that articulates positive, negative, and ambiguous aspects in their current situation. We delineate some of the defining features of the condition of contemporary youth to indicate the ways that they are encountering the challenges facing them, and to suggest how these might best be engaged. There are obviously a wide diversity of youth experiences of varying genders, races, classes, sexualities, and social groups, and we want both to suggest differences while also emphasizing what they share in common as a generation. Our argument is that within the present social crisis, there are grave dangers for youth, but also some enhanced freedoms and opportunities. More positive futures cannot be created, however, unless youth are able to achieve a variety of forms of literacy, including print, media, and computer skills and enhanced education (Kellner, 2002). These abilities will enable them to cope with a rapidly changing environment and can help the emergent generations to shape their own future and remake the culture and social world they inherit.

Today's youth are privileged subjects of the postmodern adventure because they are the first generation to live intensely in the transformative realms of cyberspace and hyperreality where media culture, computers, genetic engineering, and other emerging technologies are dramatically transforming all aspects of life (see Best and Kellner, 2001). It is a world where multimedia technologies are changing the very nature of work, education, and the textures of everyday life, but also where previous boundaries are imploding, global capital is restructuring and entering an era of crisis, war, and terrorism, while uncertainty, ambiguity, and pessimism become dominant moods.

Consequently, the youth of the new millennium are the first generation to live the themes of postmodern theory. ${ }^{2}$ Entropy, chaos, indeterminacy, contingency, simulation, and hyperreality are not just concepts they might encounter in a seminar, but forces that constitute the very texture of their experience, as they deal with corporate downsizing and the disappearance of good jobs, economic recession, information and media overload, the demands of a high-tech computer society, crime and violence, identity crises, terrorism, war, and an increasingly unpredictable future. For youth, the postmodern adventure is a wild and dangerous ride, a rapid rollercoaster of thrills and spills plunging into the unknown. 


\section{FROM BOOMERS TO BUSTERS}

Perhaps the cruelest joke played on our generation is the general belief that if you went to college, you'll get a job and be upwardly mobile.

Steven Gibb

The prospects for youth have always been problematic, dependent on class, gender, race, nationality, and the concrete sociohistorical environment of the day. "Youth" itself is a social construct that takes on different connotations at different periods in history. What is striking about the contemporary situation of youth is the totalizing and derogatory terms used to describe them. Youth have been tagged with terms such as the "Postponed Generation," the "13th Generation," the "New Lost Generation," "The Nowhere Generation," or most frequently, "Generation X," as well as "The Scapegoat Generation," "GenNet," "GenNext," and other catchphrases. ${ }^{3}$ These terms have mainly been applied to the 80 million Americans born between the 1960s and 1980s who follow the "boomer" generation that emerged in post-World War II affluence and who were the beneficiaries of an unprecedented economic expansion. Howe and Strauss (1993) see all of these young people as one cohesive group, yet they nevertheless draw distinctions between the older "Atari Wave," born in the 1960s and raised on the first video games such as PacMan and Space Invaders, the "Nintendo Wave" who played the more advanced Super Mario II and Tetris games, and the "Millennial Generation" born in the 1980s who entered the computer world. While these distinctions serve to distinguish between younger kids and those who are now thirty-somethings and ascending, video games are obviously a poor marker of distinction and do not adequately delineate important gender, race, sexual preference, and class differences among contemporary youth. Moreover, innovative computer, CD-ROM, and video technologies render video games a decreasingly central aspect of youth culture, hence the term "GenNet" has become a popular phrase to define the current generation. This task of defining today's youth, we believe, is best left to the generation in question, so we are just delineating some categories that others can take up and develop.

Contemporary youth embrace a wide array of young people, including those who helped create the Internet and others hooked on violent computer games; the latchkey kids who are home alone and the mallrats quaffing fast food in the palaces of consumption; the young activists who helped generate the antiglobalization 
and emerging peace and antiwar movements; the cafe slackers, klub kidz, computer nerds, and sales clerks; a generation committed to health, exercise, good diet, and animal rights, as well as anorexics and bulimics in thrall to the ideals of the beauty and fashion industries. Today's youth also include creators of exciting 'zines and diverse multimedia; the bike ponies, valley girls, riotgirls, and skinheads; and skaters; gangstas, low-riders, and hiphoppers of the urban sprawl, all accompanied by a diverse and heterogeneous grouping of multicultural, racial, and hybridized individuals seeking a viable identity.

Certainly, in the age range of fifteen to thirty-something, in young men and women, and in various classes and races, there are important differences to note in an increasingly complex and hybridized "generation," but they also have crucial things in common. In standard media and socio-political representations, youth is pejoratively represented as cynical, confused, apolitical (or conservative), ignorant, bibliophobic, scopophilic, and narcissistic. Youth is typically portrayed in media culture as whining slackers and malcontents suffering from severe Attention Deficit Disorder induced by MTV, remote control channel surfing, net cruising, video and computer games, and tempered by Ritalin and Prozac. Indeed, the cohorts of American youth over the past couple of decades have been widely stigmatized as "the doofus generation," "the tuned-out generation," "the numb generation," "the blank generation," "a generation of self-centered know-nothings," and "Generation Ecch!" From the Right, Allan Bloom (1986) infamously excoriated youth as illiterate and inarticulate adolescents blithely enjoying the achievements of modern science and the Enlightenment while in the throes of a Dionysian frenzy, drugged by music videos, rock and roll, and illegal substances, and ushering in "the closing of the American mind," the endgame of Enlightenment values. Such jeremiads constitute only the tip of the iceberg of hostility and resentment toward this generation by older generations, reopening a "generation gap" as wide as that between 60s youth and "the establishment."

It is our argument that negative labels and characterizations of youth are falsely totalizing. They eliminate, for example, young political activists and volunteers, bright students in opposition to the values of media culture, and the technical wizards who developed much computer software and pioneered the Internet. Moreover, pejorative characterizations of youth fail to understand that whatever undesirable features this generation possesses were in large part shaped by their present and past, and how the younger generation is an unwitting victim of the economic recession and the global restructuring of capitalism and the decline of 
democracy. As Holtz says of his own generation: "We are, perhaps more than any previous generation, a product of the societal trends of our times and of the times that immediately preceded us. The years in which we were raised-the sixties, seventies, and eighties-saw unprecedented changes in the political, social, and economic environment that, for the first time in American history, have made the future of society's young members uncertain" (1995, p. 1).

There is no widespread agreement concerning what concepts best characterize contemporary youth. During the 1980s and into the 1990s, the term "Generation X," popularized by Canadian writer Douglas Coupland (1991) has been widely adopted. For us, the " $\mathrm{X}$ " signifies the crossroads upon which the present generation stands between the modern and the postmodern. It suggests an unknown and indeterminate future, a fluidity of identities that are being redefined by new technologies and cultural experiences, and a situation of uncertainty and social chaos. Yet if one needs a label to characterize this generation, then perhaps not "Generation X," which is vague and widely rejected by those it is supposed to characterize, ${ }^{5}$ but "postboomers" is preferable, because they are the successors to those Americans born between 1945 and 1960 and their identities in large part are shaped in reaction to them and their times. Moreover, they are the first generation to grow up in the post-1960s Cold war era, characterized by the unfolding of the postindustrial society and postmodern culture and have been living in the tensions and conflicts of the "post."

The postboomer generation could also be labeled as "busters," for with this generation the American dream, enjoyed by many boomers, went bust and they were thrown into a world of uncertainty, disorder, and decline. The baby-boomers came of age during the optimism which followed World War II with the rise of suburbia, cheap education, good job opportunities, abundant housing, the Age of Affluence, and the exciting and turbulent events of the 1960s. Their children, in contrast, matured during more troubled times marked by recession, diminishing expectations, the conservative reaction led by Ronald Reagan and George Bush Senior, an explosion of shallow greed and materialism, the disillusioning drama of a dot.com boom rapidly followed by a dot.bust. The e-boom was a boom period for youth and by youth, and quite significant for this reason. Though ballooned out of proportion by the financial industries, the Internet boom represented a new economy lead by a young vanguard. The Bush II regime can be seen in many ways as a return to the old guard, the old extraction-based economy that sees economic 
advancement as a win-loss game best advanced through imperialist expansion - a shift from the consumer, innovation, and service-driven economy that envisioned (at least) a win-win world economy based on national comparative advantage and world trade. Thus, the restoration of the old order is also an attack on the Young Turks, which also has the flavor in many ways of revenge.

Moreover, dramatically worsening social conditions in the current situation emerged following the September 11 terrorist attack on the U.S. and the subsequent "war against terrorism." After declaring war against an "axis of evil" in his 2002 State of the Union speech, in early 2003 Son of Bush assembled his father's legion of doom and a gigantic military machine to wage war against Iraq in an unfolding millennium of perennial war, one that will sacrifice another generation of youth (see Kellner, 2003). Hence, while postboomer youth faced a life that was more complex, insecure, risky, and unpredictable than boomer youth, today's youth face even more dangerous and anxious times with threats of terrorism, war, and large-scale apocalypse on the horizon, as the global economy sputters and possibilities for a better life diminish. Post-postboomer youth has lived through the fallout of the rising expectations of the "new economy" and globalization, finding that dotcom.bust, terrorism, and a reactionary U.S. administration bent on a return to the past and threatening unending war has imperiled their future as well as the prospects for survival of the human species.

\section{POST-BOOMERS AND CONTEMPORARY YOUTH}

We grew up as America, in many ways, fell down.

Rob Nelson and Jon Cowan

Ultimately, it will be up to the contemporary generation to define itself, and it is time for youth and critical social theory to reflect on the Gen-Next that follows the "postboomer" generation. While the term "postboomer" helps indicates the experience of coming after the boomer generation and entering the postmodern adventure and living out the drama of the "post," the new millennium produces novel social conditions for today's youth who are engaging innovative and challenging cultural forms, and a dramatically worsening economic and political situation, and ever more complex and unpredictable life. This generation faces the challenges of forging careers in a declining economy, surviving 
the threats of war and terrorism, and overcoming the conservative hegemony that threatens their future.

There were earlier signs that postboomers were coming to resent the elderly, the "G.I." and "Silent" generations, born respectively between 1901-1924 and 1925-1942, who, through various federal programs, have grown richer as youth have grown poorer, and today's youth are bracing for a shock when 56 million boomers retire in 2010, seeking social and medical benefits that are becoming increasingly costly and scarce. ${ }^{6}$ Moreover, the postboomer/postmodern generation has been stuck with the highest federal deficit in history that it will be forced to pay off. Despite efforts of the Clinton administration to cut back on the federal deficit, future youth faced paying off a $\$ 6$ trillion debt by the year 2000, more than twenty times what it was in 1960 . This enormous mortgaging of the future is arguably the product of unwise and unfair government spending that benefited upper and middle classes over lower classes, and the middle-aged and elderly over the young (Nelson and Cowan, 1994, p. 20). During the two Reagan administrations, the national debt doubled and the Bush I administration managed to further double the deficit in one term. Further, Bush Junior is wracking up record \$304 billion dollar deficits for 2003 while $\$ 307$ billion-plus deficits are projected for the following year, and a staggering trillion dollar deficit is projected for the next five years. ${ }^{7}$ Consequently, future generations will be forced to pay for the parties for the rich and greedy thrown by Reagan and Bush administrations and will have to clean up the mess.

And so the post-generations share in common a difficult future. As Holtz realized (1995), whatever new freedoms and possibilities are available to contemporary youth-from education to jobs to housing - the opportunities to enjoy them are vanishing. The postboomers are not only the largest and most diverse of all American generations, they are "the only generation born since the civil war to come of age unlikely to match their parents' economic fortune" (Holtz, 1995, p. 7). The brief exception of the dot.com boom put Holtz's analysis in temporary question but unfortunately his subsequent comment seems appropriate where he describes the current generation as "the only one born this century to grow up personifying (to others) not the advance, but the decline of their society's greatness" (Holtz, 1995, p. 7). Once seen as a birthright of American children to inherit a better future, it is now a rite of passage to grow up in a age of decline. Indeed, various statistics add up to a grim picture of decay that shapes the cynicism and pessimism of many postboomers and contemporary youth. From cradle to the seminar room, their lives 
have been far more difficult and troubled than past generations. Childhood poverty rates, family divorces, living and education costs, taxes, violence and incarceration rates, teen pregnancy, mental illness, drug rates, obesity, cigarette smoking, and suicide rates are way up, as school performance, job prospects, median weekly earnings, unemployment benefits, and prospects of future home ownership rates are down. ${ }^{8}$

By the time the boomers' children reached puberty, optimism had thus given way to pessimism, boom to bust, opportunity to crisis, and they were "lost" in the shuffle. For many, youth was artificially prolonged as even college graduates could not get good jobs, or lost their jobs after the dot.com bust or the disasters of the post-Enron corporate collapse and catastrophe of Bushonomics. Many young people have been forced to go back to live with their parents and a second adolescence, as the perks of adulthood become ever more difficult to achieve. Yet for Holtz and others of the postboomer generation, the situation is not entirely negative. He prefers to call contemporary youth, much too optimistically, the "free generation" because "with the breakdown of many gender-based traditions and racial stereotypes, we enjoy a much broader range of lifestyle and career choices than any generation that preceded us" $(1995$, p. 3). But he also realizes that this generation is "free" of any social, cultural, or political defining generational experience that provides a common collective identity.

Indeed, in many ways, the current generation of youth is living in an especially depressing political environment. Where the boomers had the idealism of the Civil Rights movement, the Vietnam war, the counterculture, solidarity with groups involved in liberation struggles, and dreams of social revolution, their children had Watergate, the Iran hostage crisis, the Iran-Contra affair, CIA wars in Central America, S\&L scandals, cynical conservativism, dreary materialism, anxious narcissism, and the paranoia of additional terrorist attacks and the promise of a cycle of Terror Wars. Boomers watched Neil Armstrong plant a flag on the moon; postboomers and contemporary youth witnessed the Challenger and Columbia space shuttle explosions. Boomers faced the threat of bullies in the schoolyard, postboomers pass by metal detectors and security guards on their way into school and face shootings such as in the Columbine massacre. Where the boomers enjoyed Woodstock and the utopia of free love, their children had Woodstock II and then the simulacra of Woodstock III, a soulless, commodified parody of the original orchestrated by MTV, as well as "safe sex" necessitated by the specter of AIDS in a world where Eros and Thanatos are increasingly fused. 
Perhaps most crucially, while boomers enjoyed the luxury of well-funded government services, contemporary youth in the United States must now live with the consequences of the 1996 welfare reform bill, which began the process of making deep cuts in funding for women, children, and education. Of course, there are gains and advantages shared by the current generation and generational experience varies according to class, gender, race, region, and individual. While racism continues to fester and racial differences intensify, many youth of color have opportunities today denied to their parents. Although sexism continues to prevail, younger women have absorbed feminist consciousness into their everyday lives and also have more opportunities for independence than their mothers and grandmothers. And while homophobia continues to oppress gays, gay youth are out in record number and enjoying solidarity and support denied to previous generations. Also, as we indicate below, there are proliferating spaces of youth subcultures, including cyberspace, which provide opportunities for self-expression and participation denied many in the previous generations.

Crucially, the postboomers and contemporary youth share a common identity - as products and users of mass media and information technologies and a common social and political environment. They are not the first TV generation (their boomer parents had that honor), but their media experience is far more intensive and extensive. Where boomers were introduced to a TV world with limited channels in black and white, postboomers experienced the cornucopia of 50 plus channels in living color transmitted by cable and satellite television, a wealth of video cassettes, remote control devices, interactive video games, DVDs, and Kaaza. Whereas much boomer TV watching was rigorously supervised and circumscribed by concerned parents, postboomers were parked in front of the TV as a pacifier, often with both parents at work, indulging themselves in a media orgy supplemented by video and computer games.

Postboomers therefore watched much more TV than boomers, competing with the time they spent in school and with other media. ${ }^{9}$ The shows postboomers watch are of a far different nature, filled with images of sex and violence the likes of which were not seen in the 50s and early 60s, substituting in the 1990s Melrose Place, Beverly Hills 90120, and Baywatch for Ozzie and Harriet, Dobie Gillis, and Lassie. Younger viewers of the past decade watched shows like American Gladiators, The Mighty Morphin Power Rangers, Beavis and Butt-Head, and Pinky and the Brain, compared to The Howdy Doody Show, The Mickey Mouse Club, and $M r$. Ed, which entertained young boomers. And the current 
wave of "reality TV" shows feature young contestants struggling for survival, prizes, and celebrity against older players in Survivor, locked up in a panopticon of surveillance in Big Brother, and subject to the degradations of sexual and social rejection in the highly competitive personality/sex contests of Temptation Island, The Bachelor, The Bachelorette, or Joe Millionaire. These latter shows feature narcissism and sadism, depicting a highly Darwinist neo-liberal struggle for the survival of the fittest and sexiest, while losers are rejected and cast aside as unworthy.

But postboomers are also the first generation to grow up with personal computers, CD-Roms, the Internet, and the World Wide Web, providing for exciting adventures in cyberspace and proliferating technological skills, making this generation the most technologically literate in history and offering unprecedented opportunities for them to create their own culture. Peer-to-peer (P2P) sharing of music, video, computer programs, and other digitized products represents more communal and social sharing than is evident in the reality TV shows, and programs like Napster and Kazaa represent social technologies designed by youth to create a participatory and shared digital youth culture, one currently at war against the adult world of copyright litigation and the net police.

By the 1990s, forms of postmodern culture were thus a central part of youth culture. The style of MTV has influenced media culture as a whole, which absorbs and pastiches anything and everything, turning oppositional cultural forms such as hip hop and grunge into seductive hooks for fashion and advertising. The postmodern media and consumer culture is alluring, fragmented, and superficial, inviting its audiences to enter the postmodern game of consumption, style, and identity through the construction of look and image. Postmodern cultural forms are becoming dominant-at least for youth-with genre implosion a recurrent feature of contemporary film and TV, as are pastiche, sampling, hyperirony, and other features of postmodern culture. Novel forms of electronic music such as techno and rave clubs also produce cultural artifacts where youth can intensely experience postmodern culture, as they indulge in designer drugs, chemical and herbal ecstasy, and psychotropic drinks. Thus, for contemporary youth, postmodernism is not merely an avant-garde aesthetic, or academic topic, but is the form and texture of their everyday lives.

Most crucially perhaps, the experiences of the Internet have brought postmodern culture into the homes and lives of contemporary youth. Hooking into the World Wide Web, individuals can access myriad forms of culture, engage in discussions, create 
their own cultural forums and sites, establish relationships, and create novel identities and social relations in a unique cyberspace (see Turkle, 1995). Internet culture is on the whole more fragmented, diverse, and interactive than previous media culture, and as sight and sound become more integral parts of the Internet experience individuals will increasingly live in a space significantly different from previous print and media culture. Being propelled into a new cultural matrix is thus an integral part of the postmodern adventure with unforeseen results. Contemporary youth constitutes the first cybergeneration, the first group enculturated into media and computer culture from the beginning, playing computer and video games, accessing a wealth of TV channels, plugging into the Internet, and creating communities, social relations, artifacts, and identities in an entirely original cultural space for which the term "postmodern" stands as a semiotic marker.

Youth culture is thus today intersected by media and computer technologies, and the current generation has grown up in postmodern culture. Yet in opposition to the dominant media and consumer culture, youth subcultures have emerged which provide autonomous spaces where they can define themselves, creating their own identities and communities. Youth subcultures can be merely cultures of consumption where young people come together to consume cultural products, like rock music, that bind them together as a community. Yet youth subcultures can also be countercultures in which youth define themselves against the dominant culture, such as in punk, goth, or hip hop culture. Youth subcultures can comprise an entire way of life, involving clothes, styles, attitudes, and practices, and be all-involving ways of living. Youth subcultures contain potential spaces of resistance, though these can take various forms ranging from narcissistic and apolitical to anarchist and punk cultures, to activist environmental, animal rights, and Vegan groups, to rightwing skin-heads and Islamic Jihadists. Thus, although there might be elements of opposition and resistance to mainstream culture in youth subcultures, such counterculture might not be progressive and must be interrogated in specific cases concerning its politics and effects.

Of course, one needs to distinguish between a postmodern culture produced by youth itself which articulates its own visions, passions, and anxieties, and media culture produced by adults to be consumed by youth. One also needs to distinguish between youth cultures that are lived and involve immediate, participatory experience as opposed to mediated cultural experi- 
ence and consumption, and to be aware that youth cultures involve both poles. Moreover, one should resist either reducing youth cultures merely to cultures of consumption or glorifying youth culture as forces of resistance. It is best instead to ferret out the contradictions and the ways that youth cultures are constructed by media and consumer culture and the ways that youth in turn constructs its own communities and cultures.

\section{THE INTERNET, COMPUTER CULTURE, AND NEW POLITICS}

A community will evolve only when a people control their own communication.

Frantz Fanon

The Internet and multimedia computer technologies and cultural forms are dramatically transforming the circulation of information, images, and various modes of culture, and the younger generation thus needs to gain multifaceted technological skills to survive in the high-tech information society (Best and Kellner, 2001; Kellner, 2002). In this situation, students should learn both how to use computer culture to do research and gather information, as well as to perceive it as a cultural terrain which contains texts, spectacles, games, and interactive media which require a form of critical computer literacy. Youth subcultural forms range from 'zines or websites that feature an ever-expanding range of video, music, or multimedia texts to sites of political information and organization. ${ }^{10}$

Moreover, since the 1999 Seattle anti-corporate globalization demonstrations, youth have been using the Internet to inform and debate each other, organize oppositional movements, and generate alternative forms of politics and culture, some examples of which we discuss below. Consequently, we would argue that computer literacy involves not merely technical skills and knowledge, but the ability to scan information, to interact with a variety of cultural forms and groups, and to intervene in a creative manner within the emergent computer and political culture. Whereas youth is excluded for the most part from the dominant media culture, computer culture is a discursive and political location in which youth can intervene, engaging in discussion groups, creating their web sites, producing multimedia for cultural dissemination, and generating a diversity of political projects. Computer culture enables individuals to actively participate in the production of culture, ranging from discussion of 
public issues to creation of their own cultural forms, enabling those who had been previously excluded from cultural production and mainstream politics to participate in the production of culture and socio-political activism.

After using the Internet to successfully organize a wide range of anti-corporate globalization demonstrations in Seattle, Washington, Prague, Toronto, and elsewhere (see Best and Kellner, 2001), young people played an active role in organizing massive demonstrations against the Bush administration threats against Iraq, creating the basis for a oppositional antiwar and peace movement as the Bush administration threatens an era of perpetual war in the new millennium. Obviously, it is youth that fights and dies in wars which often primarily serve the interests of corrupt economic and political elites. Today's youth is becoming aware that its survival is at stake and that thus it is necessary to become informed and organized on the crucial issues of war, peace, and the future of democracy and the global economy.

Thus, as the Bush administration carried out unprecedented wars of aggression under scary preemptive strike doctrines and a new unilateralism whereby the U.S. strives to become the world's policeman and Hegemon, youth is organizing against the Bush imperialist war machine, along with veterans of past antiwar movements. And as the Bush administration carries out unprecedented attacks on democracy and civil liberties (see Kellner, 2003), some young people are exerting their civil liberties speaking out against the Bush Reich and struggling for a more democratic and egalitarian social order (while others join many of their elders in collapsing into fear, apathy, and confusion).

Likewise, groups are organizing to save endangered species, to fight genetically-engineered food, to debate cloning and stem cell research, to advance animal rights and environmental causes, and to work for creating a healthier diet and alternative medical systems. The Internet is a virtual treasury of alternative information and cultural forms with young people playing key roles in developing the technology and oppositional culture and using it for creative pedagogical and political purposes. Alternative courses in every conceivable topic can be found on the Internet, as well as topics like human rights or environmental education that are often neglected in public schools.

Thus, we would argue that a postmodern pedagogy requires developing critical forms of print, media, and computer literacy, all of which are of crucial importance in the technoculture of the present and fast-approaching future. Indeed, contemporary culture is marked by a proliferation of image machines which generate a panoply of print, sound, environmental, and diverse aes- 
thetic artifacts within which we wander, trying to make our way through this forest of symbols. And so we need to begin learning how to read these images, these fascinating and seductive cultural forms whose massive impact on our lives we have only begun to understand. Surely, education should attend to the multimedia culture and teach how to read images and narratives as part of media/computer/technoculture literacy.

Such an effort would be linked to a revitalized critical pedagogy that attempts to empower individuals so that they can analyze and criticize the emerging technoculture, as well as participate in producing its cultural and political forums and sites. The challenge for education today is thus to promote computer and media literacy to empower students and citizens to use a wide range of technologies to enhance their lives and create a better culture and society. In particular, this involves developing Internet projects that articulate with important cultural and political struggles in the contemporary world and developing relevant educational material (see Best and Kellner, 2001; Kellner, 2002; Kahn and Kellner, forthcoming).

Yet, there is also the danger that youth will become excessively immersed in a glittering world of high-tech experience and lose its social connectedness and ability to communicate and relate concretely to other people. Statistics suggest that more and more sectors of youth are able to access cyberspace and that college students with Internet accounts are spending as much as four hours a day in the seductive realm of technological experience. The media, however, has been generating a moral panic concerning allegedly growing dangers in cyberspace with sensationalistic stories of young boys and girls lured into dangerous sex or running away, endless accounts of how pornography on the Internet is proliferating, and the publicizing of calls for increasing control, censorship, and surveillance of communication-usually by politicians who are computer illiterate.

To be sure, there are perils in cyberspace as well as elsewhere, but the threats to adolescents are significantly higher through the danger of family violence and abuse than seduction by strangers on the Internet. And while there is a flourishing trade in pornography on the Internet, this material has become increasingly available in a variety of venues from the local video shop to the newspaper stand, so it seems unfair to demonize cyberculture. Indeed, attempts at Internet censorship are part of the attack on youth which would circumscribe their rights to obtain entertainment and information, and create their own subcultures. Devices like the V-chip that would exclude sex and violence on television, or block computer access to objectionable 
material, is more an expression of adult hysteria and moral panic than genuine dangers to youth which certainly exist, but much more strikingly in the real world than in the sphere of hyperreality.

Yet there is no doubt that the cyberspace of computer worlds contains as much banality and stupidity as real life and one can waste much time in useless activity. But compared to the bleak and violent urban worlds portrayed in rap music and youth films like Kids, the technological worlds are havens of information, entertainment, interaction, and connection where youth can gain valuable skills, knowledge, and power necessary to survive the postmodern adventure. Youth can create more multiple and flexible selves in cyberspace as well as alternative subcultures and communities. Indeed, it is exciting to cruise the Internet and to discover how many interesting websites young people and others have established, often containing valuable educational material. There is, of course, the danger that corporate and commercial interests will come to colonize the Internet, but it is likely that there will continue to be spaces where individuals can empower themselves and create their own communities and identities. A main challenge for youth (and others) is to learn to use the computer and information technology for positive cultural and political projects, rather than just entertainment and passive consumption.

Reflecting on the growing social importance of emerging technologies and cultural sites makes it clear that it is of essential importance for youth today to gain various kinds of literacy to empower themselves for the emerging cybersociety. To survive in a postmodern world, individuals of all ages need to gain skills of media and computer literacy to enable themselves to negotiate the overload of media images and spectacles. We all need to learn technological skills to use the multimedia and computer technologies to subsist in the emerging high-tech economy and to form our own cultures and communities. And youth especially need street smarts and survival skills to cope with the drugs, violence, and uncertainty in today's predatory culture (McLaren, 1995) and emerging era of Terror War (see Giroux, 2003b).

It is therefore extremely important for the future of democracy to make sure that youth of all classes, races, genders, and regions gain access to multimedia technology and critical pedagogies. They need training in media and computer literacy skills in order to provide the opportunities to enter the high-tech job market and society of the future, and to prevent an exacerbation of class, gender, and race inequalities. And while multiple literacy skills will be necessary, traditional print literacy skills are all the more important in a cyberage of word-processing, in- 
formation gathering, and cybercommunication. Moreover, training in philosophy, ethics, value thinking, and the humanities is necessary now more then ever. Indeed, how emergent technologies will be used depends on the overall education of youth and the skills and interests they bring to the technologies that can be used to access educational and valuable cultural material, or pornography and the banal wares of cybershopping malls.

Of course, cyberlife is just one dimension of experience and individuals still need to learn to interact in a "real world" of school, jobs, relationships, politics, and other people. Youth-and all of us-need to learn to interact in many dimensions of social reality and to gain a variety of forms of literacy and skills that will enable us to create identities, relationships, and communities that will nurture and develop our full spectrum of potentialities and satisfy a wide array of needs. Our lives are more multidimensional than ever, and part of the postmodern adventure is learning to live in a variety of social spaces and to adapt to intense change and transformation. Education too must meet these challenges and use multimedia and information technologies to promote empowering learning and devise strategies to create a more democratic and egalitarian multicultural society.

\section{Notes}

1. This analysis was to be included in our book The Postmodern Adventure, but the study was cut from the final version because of space considerations. Examples here are drawn from our studies of youth in the United States, but in an increasingly globalized world such specificities often have more general relevance. Thanks to Richard Kahn and Andrew Thomas for extremely useful critiques of an earlier version of this text and to Henry Giroux for long-time support of our work.

2. On postmodern theory, see Best and Kellner (1991, 1997, 2001).

3. Coined by Strauss and Howe (1993), the term "13th Generation" refers to the thirteenth generation of American citizens, born in the 1960s. As coincidence would have it, their's is an unlucky number. "Generation X," popularized by Douglas Coupland (1991), signifies blankness and confusion, and is taken from a British boomer rock band. Mike Miles (1996) uses the term the "scapegoat generation" for those youth who are blamed for the social ills which were in large part produced by older generations. Many people, however, do not feel part of either the boomer or postboomer generation, and are somewhere in between, hence they are baptized "tweeners" (USA Today, March 22, 1996). Technically, by their date of birth, they belong to the boomers, but in their cynical and pessimistic mindset they are much closer to the postboomers.

4. Exceptions to the negative image of the cynical, apolitical slacker stereotype, include Nelson and Cowan (1994), which features an analysis of the debt crisis and suggestions for how youth can intervene politically to help 
others and shape a brighter future for themselves, moving from unplugged to plugging back in; but their "Lead or Leave" foundation has been heavily funded by conservative sources and they have stressed cutting back on the federal deficit through cutting back on social security and welfare programsprecisely the Republican agenda (see the critique in Extra!, Vol. 7, No. 2 (March/April 1994), pp. 6-7). See also Males (1996) who explodes the myths that contemporary youth are themselves responsible for exploding violence, crime, teen pregnancies, and social disorder, and for recent studies and critiques of the escalating attacks on youth, see Giroux $(2000,2003)$.

5. A Newsweek cover story on "The Myth of Generation X" already by 1994 claimed that "a recent MTV poll found that only one in 10 young people would ever let the phrase 'Generation X' cross their lips" and cited several who rejected the label (June 6, 1994, p. 64).

6. See Coupland (1991: 181-183) who cites statistics indicating the growing amount of federal wealth and programs directed toward the elderly and increased tax burdens for younger generations. Third Millennium founder Jonathan Karl noted that in 1995, the federal government spent 11 times more on each senior citizen than it did on each child under 18 and warned of generational warfare if the budget deficit and high tax burdens on the young are not dealt with; in Swing (September 1996): 53f. Obviously, as we note here, the Bush administration is creating staggering deficits that will constitute a daunting challenge to future generations.

7. Elizabeth Bumiller, "Bush's \$2.2 Trillion Budget Proposes Record Deficits," New York Times (February 4, 2003). Although the U.S. economy has gone into decline since the 1970s, this skid has hit the young generation the hardest, and they remain the poorest and most exploited. According to the U.S. Bureau of the Census, only 0.3 million Americans over age 65 lacked health insurance in 1990, while 14.8 million between ages 18 to $34 \mathrm{did}$, as did 8.4 million under age 18 (Howe and Strauss, 1993, p. 108). As Nelson and Cowan warn, "unless America dramatically shifts our budget priorities over the next 10 to 15 years to create new policies that are fair to all generations, we will confront an unprecedented battle between the baby boomers and everyone born after 1960" (1994, p. 58). The U.S. Bureau of the Census found that childhood poverty rates rose from 15 percent in 1970 to over 20 percent in 1990, as poverty rates for the elderly plummeted from 25 percent to 12 percent during the same period (Howe and Strauss 1993, p. 35). In the United States today, more than one out of every five people under the age of 18 lives in poverty, a number a Tufts University study predicts will rise to more than one out of four by 2021 (Nelson and Cowan 1994, p. 40). The U.S. Bureau of Labor Statistics reported that in 1960, only 20 percent of mothers with children under the age of 6 worked, a number that tripled by 1990 . For mothers with children ages $6-17$, these numbers rose from 43 to 76 percent during the same years (Howe and Strauss 1993, p. 58). Children born in 1968 faced three times the risk of parental break-up as children born in 1948 and fewer than half of busters reach their mid teens with two once-married biological parents (ibid., pp. 59, 61). Other relevant statistics can be found in Howe and Strauss 1993; Nelson and Cowan (1994); Holtz (1995); and Giroux (2003) who traces out the growing impoverishment of youth and expanding class divisions in the Bush administration.

8. See the statistics on these issues in Howe and Strauss (1993); Holtz (1995), Hammer ( 2002), and Giroux (2003). 
9. By the age of five, boomers had seen little or no TV, compared to the 5,000 hours of viewing by their post-boomer children (Howe and Strauss 1993). According to some statistics, "the average 14 year old watches on average three hours of television a day, and does one hour of homework" (Howe and Strauss, 1993). Data on time spent by teenagers on TV is available in Robinson (1992); Robinson and Godbey (1997); Robinson, Kestnbaum, Neustadtl, and Alvarez (2000); Larson, and Verma (1999); and Larson, Richards, et al. (2001). On youth Internet use, see Fox, and Rainie ( 2001) and Jones (2000).

10. See Jones (2002) and Kahn and Kellner (forthcoming). Some good sites that exhibit youth voices, participation, and response include http:// www.moveon.org; http://www. raisethefist.com; http://www.tao.com; and the youth blog site at http://www. bloghop. com/ topics.htm?numblogs=14566\&cacheid=1044419966.3569.

\section{REFERENCES}

Best, Steven, and Kellner, Douglas. (1991). Postmodern Theory: Critical Interrogations. London and New York: MacMillan and Guilford Press. (1997). The Postmodern Turn. New York: Guilford Press. (2001). The Postmodern Adventure: Science, Technology, and Cultural Studies at the Third Millennium. New York: Guilford.

Bloom, Allan. (1987.) The Closing of the American Mind. New York: Simon and Schuster.

Coupland, Douglas. (1991). Generation X: Tales for an Accelerated Culture. New York: St. Martin's Press.

Epstein, Jonathan S., editor. (1988). Youth Culture. Identity in a Postmodern World. Malden, MA and Oxford, UK: Blackwell.

Giroux, Henry. (1996). Border Crossing. New York: Routledge. (2000). Stealing Innocence. Youth, Corporate Power, and the Politics of Culture. New York: Saint Martin's Press. (2003). "Neoliberalism's War Against Youth: Where are Children in the Debate About Politics?" (forthcoming). (2003b). The Abandoned Generation. Democracy Beyond the Culture of Fear. New York: Palgrave Macmillan.

Hammer, Rhonda. (2002). Antifeminism and Family Terrorism. Lanham, MD: Rowman and Littlefield.

Holtz, Geoffrey T. (1995). Welcome to the Jungle: The Why Behind 'Generation X'. New York: St. Martin's Press.

Howe, Neil and Strauss, Bill. (1993). 13th Generation: America's 13th Generation, Born 1961-1981. New York: Vintage.

Jones, S. (2002). The Internet Goes to College: How Students Are Living in the Future With Today's Technology. Washington, D.C.: Pew Internet and American Life Project.

Kahn, Richard and Kellner, Douglas. (forthcoming). "Internet Subcultures and Oppostional Politics" in David Muggleton, Ed., The Post-Subcultures Reader (Muggleton, David, ed.). Oxford and New York: Berg.

Kellner, Douglas. (2002). "Technological Revolution, Multiple Literacies, and the Restructuring of Education," in Ilana Snyder, Ed., Silicon Literacies. London and New York: Routledge. PP. 154-169.

(forthcoming). From September 11 to Terror War: The Dangers of the Bush Legacy. Lanham, MD: Rowman and Littlefield. 
Larson, R. and Verma S. (1999). "How children and adolescents spend time across cultural settings of the world: Work play and developmental opportunities." Psychological Bulletin, 125: 701-736.

Larson, R., Richards, M. H. , et al. (2001). "How urban African American young adolescents spend their time: Time budgets for locations, activities, and companionship." American Journal of Community Psychology, 29(4): 565597.

Males, Mike. (1996.) The Scapegoat Generation. Boston: Common Courage Press. McLaren, Peter. (1995). Critical Pedagogy and Predatory Culture. London and New York: Routledge.

Nelson, Rob and Cowan, Jon (1994) Revolution X: A Survival Gudie for Our Generation. New York: Penguin Books.

Robinson, J. P. (1992). “Television and leisure time: Yesterday, Today and (maybe) Tomorrow." Public Opinion Quarterly 33: 210-222.

Robinson, J. P. and Godbey G. (1997). Time for life: The surprising ways Americans use their time. University Park, PA: Pennsylvania State University Press.

Robinson, J. P., Kestnbaum, Meyer, Neustadtl, Alan, and Alvarez, Anthony (2000). Information Technologies, the Internet, and Time Displacement. Retrieved May 16, 2000, from www.webuse.umd.edu <http:// www.webuse.umd.edu/.

Turkle, Sherry. (1995). Life on the Screen. Identity in the Age of the Internet. 
Copyright $\odot 2003$ EBSCO Publishing 